\title{
Placental Ultrastructural Changes and Apoptosis in Pregnancies with Meconium Stained Amniotic Fluid
}

\author{
Mekonyumlu Amnion Sıvısı Olan Gebeliklerde Plasental İnce Yapısal \\ Değişiklikler ve Apoptozis
}

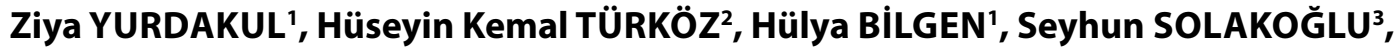 \\ Sultan KAVUNCUOĞLU' ${ }^{4}$, Eren ÖZEK ${ }^{1}$ \\ Departments of ${ }^{1}$ Pediatrics and ${ }^{2}$ Pathology, Marmara University, Faculty of Medicine, ISTANBUL, TURKEY \\ ${ }^{3}$ Department of Histology and Embryology, istanbul University, Faculty of Medicine, ISTANBUL, TURKEY \\ ${ }^{4}$ Department of Pediatrics, istanbul Bakırköy Maternity and Children Diseases Education and Research Hospital, iSTANBUL, TURKEY
}

\begin{abstract}
Objective: The cause of meconium stained amniotic fluid in term healthy pregnancies is not clearly understood yet. The aim of this study was to investigate the placental ultrastructural changes and placental apoptosis in pregnancies complicated with meconium stained amniotic fluid.

Material and Method: The study group was composed of mothers (n: 13) and their term, appropriate for gestational age newborns with meconium stained amniotic fluid but without meconium aspiration syndrome. The control group consisted of mothers (n: 24) and their term appropriate for gestational age babies. We studied placental ultrastructural changes by transmission electron microscopy and placental apoptosis by transmission electron microscopy and the TUNEL method.
\end{abstract}

Results: The incidence of placental apoptosis by the TUNEL method was significantly higher in the study group compared to the control group. Transmission electron microscopy investigation revealed more remarkable ultrastructural changes in the study group compared to the control group.

Conclusion: The increased apoptosis and ultrastructural findings in placentas with meconium stained amniotic fluid may be related to the placental adaptation to the hypoxic fetuses.

Key Words: Meconium, Placenta, Apoptosis öz

Amaç: Sağlıklı gebeliklerde amnion sıvısında mekonyum bulunmasının sebebi henüz tam anlaşılamamıştır. Bu çalışmanın amacı amnion sıvılarında mekonyum bulunan gebeliklerde plasental ince yapısal değişiklikleri ve plasental apoptozisi araştırmaktır.

Gereç ve Yöntem: Çalışma grubu mekonyumlu amnion sıvısı olan, ancak mekonyum aspirasyon sendromu gelişmemiş olan miadında ve gestasyonel süreyle uyumlu yenidoğanlar ile annelerinden oluşturuldu (n: 13). Kontrol grubu ise anneler ile sağlıklı miadında ve gestasyonel süreyle uyumlu yenidoğanlardan oluştu (n: 24). Plasental ince yapısal değişiklikler transmisyon elektron mikroskopisi ile, plasental apoptozis ise transmisyon elektron mikroskopisi ve TUNEL metoduyla değerlendirildi.

Bulgular: TUNEL ile apoptozis insidansı çalışma grubunda kontrol grubuna göre yüksek bulundu. Transmisyon elektron mikroskopisi ile çalışma grubunda kontrol grubuna göre daha belirgin ince yapısal değişiklikler görüldü.

Sonuç: Mekonyumlu amnion sıvısı olan plasentalardaki artmış apoptozis ve ince yapısal değişiklikler plasentanın fetustaki hipoksiye karşı oluşan adaptasyon sürecini yansıtıyor olabilir.

Anahtar Sözcükler: Plasenta, Mekonyum, Apoptozis

\section{INTRODUCTION}

Intrauterine meconium passage complicates approximately 10 to $15 \%$ of all pregnancies and there are controversies about the pathophysiology of the process (1). This process has been reported to be a physiological process or related to chronic intrauterine hypoxia.
Placental apoptosis occurs under the influence of physiological and pathological stimuli and it has been shown to play a major role in the structural and functional development of normal placenta (2-6). It has also been theorized that increased placental apoptosis may contribute to the pathophysiology of intrauterine growth restriction, preeclampsia and intrauterine meconium passage (79). Korkmaz et al. showed that the incidence of placental

Correspondence: Hüseyin Kemal TÜRKÖZ

Department of Pathology, Marmara University, Faculty of Medicine, İSTANBUL, TURKEY

E-mail: kemal.turkoz@marmara.edu.tr Phone: +90 2166452525 
apoptosis was significantly higher in pregnancies with intrauterine meconium passage (10). There are studies that focus on the relationship of placental pathology and pregnancy outcome such as meconium staining in complicated pregnancies like diabetes mellitus, intrauterine infections, intrauterine growth restriction, and preeclampsia $(8,7,11,12)$. However there is limited data regarding placental morphology and apoptosis in uncomplicated pregnancies with meconium stained amniotic fluid. We evaluated placental morphology and extent of apoptosis in uncomplicated pregnancies with meconium stained amniotic fluid.

\section{MATERIAL and METHODS}

This study was carried out in the Marmara University School of Medicine, Istanbul, Turkey. The project was approved by the hospital's ethical committee.

The study group was composed of mothers (n: 13) and their appropriate for gestational age (AGA) newborns with meconium stained amniotic fluid (MSAF), but without meconium aspiration syndrome. The control group (n: 24) was selected at random and consisted of mothers and their AGA babies.

Exclusion criteria were pregnancies complicated by gestational disorders such as gestational diabetes, hypertension, preeclampsia, chorioamnionitis, prolonged rupture of membranes, maternal chronic diseases, smoking and babies with congenital malformations, chromosomal anomalies, intrauterine growth retardation (IUGR), perinatal hypoxia, multiple gestation and meconium aspiration syndrome.

Prenatal and natal history including gestational age, gravidity, parity, results of obstetric ultrasound examination, type of delivery and APGAR scores were recorded. All infants were examined and followed up 24-48 hours postnatally.

Following the delivery, the umbilical cord was double clamped and blood samples were taken from the umbilical cord artery for blood gases. We excluded the cases with a $\mathrm{pH}$ lower than 7.1, and an APGAR score lower than 7 at 1 or 5 minutes because our study design dictated that MSAF and control infants should not have asphyxia.

Pathological specimens: Each placenta was examined macroscopically after delivery for gross pathology including color change of placental membranes, infarct, calcification, intervillous or fetal vessel thrombus and retroplacental hemorrhage, and then fixed in $10 \%$ formalin. Two placentas were excluded because of major large infarct and intervillous thrombus. Samples from 8 randomly chosen placentas (4 from each group) were taken for electron microscopy before formalin fixation. Two $2 \times 2 \times 0.5 \mathrm{~cm}$ full-thickness samples at $5 \mathrm{~cm}$ from the peripheral edge of each placenta were fixed in $2.5 \%$ phosphate-buffered glutaraldehyde solution.

Each formalin fixed placenta was re-examined for gross pathology following fixation, and four $2 \times 2 \times 0.5 \mathrm{~cm}$ fullthickness placental samples at $5 \mathrm{~cm}$ from the peripheral edge of each placenta were fixed in formalin for 24 hours at $4^{\circ} \mathrm{C}$ and were paraffin embedded following processing. We decided that more samples were not necessary because the apoptotic ratios in different parts of placentas have been reported to be similar in previous studies (5). Five $4 \mu \mathrm{m}$ sections from each paraffin block were cut and mounted on microscope slide, and then stained with hematoxylin and eosin (H\&E) for light microscopy. H\&E stained and TUNEL (Terminal deoxynucleotidyl Transferase Biotin-dUTP Nick End Labeling) stained slides were evaluated with the Olympus CX31-Tokyo, Japan microscope. After microscopic examination of all $\mathrm{H} \& \mathrm{E}$ stained slides, one block from each placenta with representative changes was chosen for TUNEL staining to calculate the apoptotic index. H\&E stained slides were evaluated for the presence of fibrinoid necrosis of the villi, calcification, increased intervillous (perivillous) fibrin deposition, villous agglutination, villous edema, amount of syncytial knots, meconium stained macrophages and congestion of fetal vessels. While evaluating these morphological characteristics, we used the criteria defined by CAP to ensure uniformity of slide interpretation $(13,14)$.

TUNEL staining: Two $4 \mu \mathrm{m}$ sections from the formalinfixed, paraffin-embedded tissue block were placed on poly1-lysine-coated slides. The tissue sections were kept at $60{ }^{\circ} \mathrm{C}$ in an oven overnight before staining. The TUNEL technique was used to detect regular single strand DNA breaks that are typical for apoptosis (In Situ Cell Death Detection Kit, POD, Roche). The manufacturer's instructions were followed with the following few modifications.

After dewaxation and rehydration, tissue sections were protein-digested using proteinase $\mathrm{K}$ for 30 minutes. The background was diminished by preincubating samples with $3 \%$ bovine serum albumin (BSA), 20\% normal bovine serum in $0.1 \mathrm{M}$ Tris- HCL for 30 minutes at 15 $25^{\circ} \mathrm{C}$. The samples were then exposed for 1 hour at $37^{\circ} \mathrm{C}$ in a moist chamber to the TUNEL reaction mixture and label solution for the negative control. Then, converterPOD was added on samples and color was developed using DAB (diaminobenzidin). Each section was examined at magnification of $\mathrm{x} 400$ by single observer to prevent 
interobserver error. The observer was blinded as to whether the sections being counted were from normal or MSAF pregnancies.

A cell was defined as apoptotic if the nucleus of the cell was stained homogenous and strong dark brown (Figure 1). There was a dark brown condensation of the heterochromatin in apoptotic nuclei. At high magnification, an average of 20,000 cells (trophoblastic and stromal cells) was counted for each placenta.

The number of apoptotic cells was expressed as percentage of the total number of cells counted. (Percentage of apoptotic cell= Number of apoptotic cells X100/ total number of cells counted).

Electron microscopy was performed on 4 random cases from each group. For transmission electron microscopy

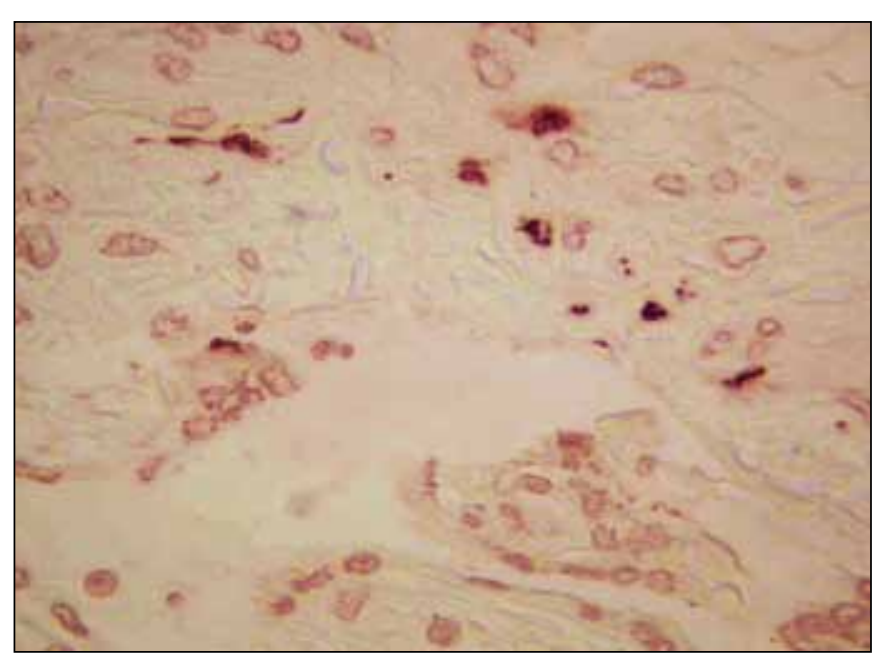

Figure 1: Trophoblastic cells are seen. Apoptotic trophoblastic cells are dark brown (stained by the TUNEL method of placental tissue in the meconium group, original magnification $\mathrm{x} 400$ ).
(TEM), placental sections were fixed in $2.5 \%$ phosphatebuffered glutaraldehyde solution. Following routine tissue processing, tissue blocks were embedded in epoxy resin. Toluidine blue stained sections of $1 \mu \mathrm{m}$ from epon embedded block were examined in Olympus BH-2 photomicroscope after which $60 \mathrm{~nm}$ sections were cut and stained with uranyl acetate and lead citrate and then evaluated in a JEOL 1200 EX TEM.

Statistical analysis was performed by SPSS 11.5 for Windows. Minimum, maximum and median values were used, because all data were non parametric. The significance test used was the Mann-Whitney U test. A p value of $<0.05$ was accepted as statistically significant.

\section{RESULTS}

Demographic characteristics of the study and control groups are given in Table I. There was no statistically significant difference between the two groups. All newborns in the study and control groups had normal physical examinations and blood gases. No newborns were admitted to the neonatal intensive care unit.

Macroscopic examination of the placentas in the study group showed yellowish green or green discoloration of placental membranes. No gross placental pathology was noted in the control group. Microscopic examinations of placentas in both groups did not show any significant pathological changes for fibrinoid necrosis of the villi, calcification, increased intervillous (perivillous) fibrin deposition, villous agglutination, villous edema, amount of syncytial knots and congestion of fetal vessels. There were meconium stained macrophages in the chorionic plate of the placentas of study group. No meconium laden macrophage was identified in the control group (Table II).

Table I: Demographic characteristics of the study and control groups

\begin{tabular}{|l|c|c|c|}
\hline & $\begin{array}{c}\text { Study Group n:13 } \\
\text { median (min-max) }\end{array}$ & $\begin{array}{c}\text { Control Group n:24 } \\
\text { median (min-max) }\end{array}$ & p \\
\hline Birth Weight $(\mathrm{g})$ & $3120(2500-3670)$ & $3260(2700-3700)$ & 0.31 \\
\hline Height (cm) & $50(48-53)$ & $50(47-53)$ & 0.87 \\
\hline Head circumference (cm) & $34(34-36)$ & $34(33-36)$ & 0.87 \\
\hline Gestational age (week) & $40(37-41)$ & $40(38-41)$ & 0.92 \\
\hline APGAR 5.minute & $9(8-10)$ & $9(9-10)$ & 0.31 \\
\hline Male /Female & $7 / 6$ & $11 / 13$ & 0.74 \\
\hline Maternal age (year) & $27(19-36)$ & $24(19-31)$ & 0.06 \\
\hline Parity & $1(1-2)$ & $1(1-3)$ & 0.34 \\
\hline Delivery mode (c-s/normal) & $2 / 11$ & $0 / 24$ & 0.11 \\
\hline Placental Weight (g) & $610(390-730)$ & $555(380-760)$ & 0.59 \\
\hline
\end{tabular}


The mean umbilical cord arterial blood $\mathrm{pH}$ of the control group was $7,31(\mathrm{SD}=0.07)$ while the mean $\mathrm{pH}$ of the MSAF group was $7.23(\mathrm{SD}=0,07)$. Control vs $\mathrm{MSAF} \mathrm{pCO}_{2}$ was $53,38(\mathrm{SD}=0,60)$ and $53,73 \mathrm{mmHg}(\mathrm{SD}=0.69) ; \mathrm{pO}_{2}$ $17.32(\mathrm{SD}=0.26)$ vs. $17,14 \mathrm{mmHg}(\mathrm{SD}=0.26)$, bicarbonate 22.20 ( $\mathrm{SD}=0.43)$ vs. $22.52 \mathrm{mmol} / \mathrm{L}(\mathrm{SD}=0.46)$. Differences between these values were statistically significant for $\mathrm{pH}$ only $(\mathrm{p}=0.049$ for $\mathrm{pH}, 0.067$ for bicarbonate, 0.062 for $\mathrm{pO}_{2}$ and 0.058 for $\mathrm{CO}_{2}$ ). Although higher levels of $\mathrm{pCO}_{2}$, bicarbonate and lower levels of $\mathrm{pO}_{2}$ and $\mathrm{pH}$ point to a hypoxia in the fetal blood, the differences were statistically significant only for $\mathrm{pH}$ levels. Significance and difference in $\mathrm{pH}$ value was also subtle, indicating a very slight hypoxia in the fetus.

TEM investigation of the 4 cases in the study group showed morphological changes which were not seen in the control group (Table II, Figure 2A). Although results of the light microscopic examinations of both groups were not significantly different, TEM investigation revealed separation of basal membranes in villous capillaries (Figure 2B), significant thickening of the basal membranes of the cytotrophoblasts (Figure 2A) blebbing of endothelial cells in terminal villi with vacuolated cytoplasms (Figure 2C), deposition of collagen (Figure 2B), and apoptosis (Figure 2D) seen in all four cases of the study group. No such changes were observed in the control group.

The incidence of placental apoptosis by TUNEL method was significantly higher in the study group than the control group (median [min-max]: $0.18 \%[0.10-0.28]$ vs. $0.12 \%$ [0.04-0.21], $\mathrm{p}=0.002$ )

\section{DISCUSSION}

We evaluated placental morphology by light and electron microscopy and placental apoptosis by the TUNEL method in meconium stained but uncomplicated pregnancies and healthy term births in this study. We found an increase in placental apoptosis and ultrastructural changes in the meconium stained group compared with the control group.

We used H\&E stained slides to evaluate the presence of fibrinoid necrosis, calcification, increased intervillous (perivillous) fibrin deposition, villous agglutination, villous edema, amount of syncytial knots, meconium stained macrophages and congestion of fetal vessels. Only meconium stained macrophages were significantly different between the groups. Light microscopic examination of H\&E stained slides showed that all the placentas of the study group had meconium stained macrophages while there was no meconium stained macrophage in the control group. Meconium laden macrophages in chorionic plate or subamniotic connective tissue are reported to be indicative of mecomium passage to amniotic fluid 2-3 hours before delivery $(15,16)$. Our findings suggest that meconium staining in the study group was not acute and fetuses were exposed to meconium for at least 2-3 hours. Absence of meconium laden macrophages in the control group indicated that there was no microscopic meconium discharge in the amniotic

Table II: Histopathological and ultrastructural findings in placental tissue samples of the study and control groups

\begin{tabular}{|l|c|c|}
\hline Light microscopy & Study group n (\%) & Control group (n:24) $\mathbf{n}(\%)$ \\
\hline Focal necrosis $\left(^{*}\right)$ & $6(46.1)$ & $13(54.1)^{\dagger}$ \\
Focal calcification & $2(15.5)$ & $5(20.8)^{\dagger}$ \\
Increased fibrin deposition ( $\ddagger)$ & $4(30.7)$ & $9(37.5)^{\dagger}$ \\
Villous agglutination & $2(15.3)$ & $4(16.6)$ \\
Villous edema & $1(7.7)$ & $3(12.5)^{\dagger}$ \\
Increased syncytial knots & $4(30.7)$ & $5(20.8)^{\dagger}$ \\
Congestion of fetal vessels & $7(53.8)$ & $11(45.8)^{\dagger}$ \\
Meconium stained macrophage & $13(100)$ & $0(0)$ \\
\hline Transmission electron microscopy & Study Group (n:4) & Control Group (n:4) \\
\hline Vacuolization & Present, diffuse & Absent \\
Basal membrane thickening & Present, diffuse & Absent \\
Collagen deposition & Present, diffuse \\
Apoptosis & Present, focal & Present, focal \\
\hline Apoptosis \% by TUNEL method & & \\
median (min-max) & $0.18(0.10-0.28) \mathrm{n}: 13$ & $0.12(0.04-0.21) \mathrm{n}: 24$ \\
\hline
\end{tabular}

$\left({ }^{\star}\right)$ Fibrinoid necrosis of the villi. ( () Perivillous (intervillous) fibrin deposition. 

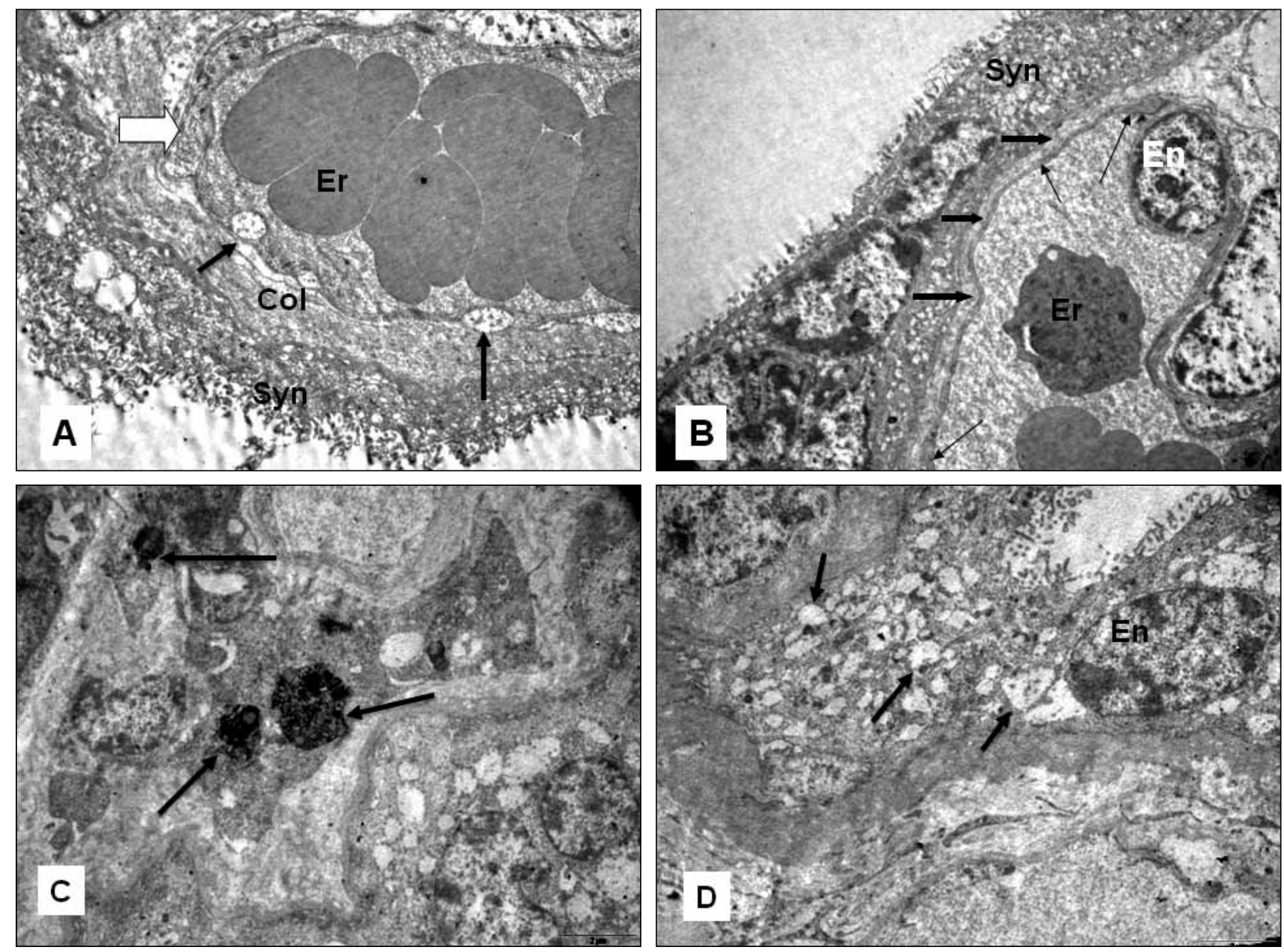

Figure 2: Ultrastructural changes in the control group. A) Separation of basement membrane of the endothelium and increase in collagen. Er: erythrocyte in the fetal capillary, Col: increased collagen. Arrows: Separation in the basement membrane, Open arrow: nucleus of the endothelial cell. Syn: Syncytiotrophoblast. B) Thickening of the basement membrane. Er: erythrocyte in the fetal capillary, Syn: Syncytiotrophoblast, En: Nucleus of the endothelial cell, Thin arrows: Cytoplasm of the endothelial cell, Thick arrows: Thickened basement membrane C) Apoptotic cell. Arrows: Apoptotic bodies. D) Cytoplasmic vacuolisation in endothelial cell. En: Nucleus of the endothelial cell. Arrows: Vacuoles.

fluid. Microscopic examination for other histopathological parameters in both groups did not show any significant pathological changes indicating placental insufficiency, chorioamnionitis, hypertension or major placental ischemic changes.

Apoptosis is energy dependent and modulated by diverse environmental and genetic clues and may also be a response of tissue hypoxia $(2,5,6)$. Placental apoptosis is involved in placental homeostasis, growth and remodeling (4). Smith et al. studied the role of placental apoptosis in intrauterine growth restriction. They suggested that an increase in the apoptotic index could be a result of the pathological processes leading to intrauterine growth retardation (IUGR) or cause of IUGR (8).
The pathophysiological mechanism of intrauterine meconium passage of fetuses is not clearly understood yet. Physiological events, response to acute or chronic hypoxia, and decreased clearance of amniotic fluid have been suggested to play a role in this process $(1,2,17)$. It has been recognized recently that prolonged meconium exposure to the surface of the cord can cause partial necrosis of umbilical vessels and cord ulceration (18). The noxious moiety of meconium also causes contraction of the umbilical vessels, leading to fetal hypoperfusion and hypoxia (19). Altshuler et al. argued that direct injury of vascular smooth muscle and umbilical or placental vasoconstriction by meconium components such as bile acid resulted in ischemia and hypoxia (16). The diffusion of the meconium substances 
into the fetal circulation could cause vasoconstriction in the fetal lungs, brain, and other organs $(11,12)$.

Jazayeri et al. showed that fetal erythropoietin levels were increased in pregnancies complicated with intrauterine meconium passage, suggesting chronic intrauterine hypoxia (20). Increased placental apoptosis in pregnancies complicated with MSAF was shown in some studies (10, 15). King et al. suggested that increased placental apoptosis in MSAF could be due to prolonged exposure to an unknown constituent in meconium (15). Korkmaz et al. thought that increased placental apoptosis could be either a causative factor in MSAF or the result of the direct effect of meconium on the placental cells. They reported increased apoptosis in placentas with MSAF in their excellent article, but they did not evaluate accompanying ultrastructural changes (10).

Although apoptotic cells have relatively distinctive morphological features, they remain difficult to identify on $\mathrm{H} \& \mathrm{E}$ sections. Counting apoptotic cells by light microscopy was a subjective and repetitive process that was open to a great deal of individual interpretation. Validation of the light microscopic findings with the combination of EM is vital (4). EM remains the gold standard in the identification of apoptotic cells (21). However, because of extremely low incidence of apoptosis in the placental tissue, it would be very difficult to use EM to quantify apoptosis in the placenta. In our study, we used EM qualitatively in addition to the TUNEL method that is different from the previous studies. There was a statistically significantly increased apoptosis in rgw study group by TUNEL. However, the number of apoptotic cells we encountered was so few that we could not compare the number of apoptotic cells in both groups quantitatively by TEM.

Some certain ultrastructural changes, particularly basement membrane thickening, predict limited oxygen transfer to the fetus that may cause fetal hypoxia (22). An increase in thickness of the basement membranes and separation in the basement membrane of the trophoblast was found in the chronic hypoxic state in a study on Nepalese women (23). Therefore, hypoxia may be result or cause of basal membrane thickening and separation. We found changes indicating cellular injury such as vacuolisation of the endothelial cells, and separation and increase in the thickness of the basement membrane in our study group. These changes indicate disarrangement in maternofetal interface and suggest a failure of oxygen transfer to fetus from placenta. There is a positive correlation between amount of stromal collagen and oxygen tension. Thus, an increase in stromal collagen fibers indicates a nonhypoxic terminal villus (22). Macara et al. stated that an increase in stromal collagen fibers with thickening of the basal lamina implied a hypoxic state in the fetus while oxygen tension in the terminal villi was normal (22). We also found thickening of the basal lamina and an increase in stromal collagen. Our ultrastructural findings argue a terminal villus with normal oxygen levels and impaired oxygen transfer to the fetus implicating a hypoxic fetus. Subtle fetal hypoxia may lead to ultrastructural changes like basement membrane thickening, separation of trophoblastic membranes and increase in stromal collagen which further disrupts oxygen transfer from maternal to fetal blood. These changes, in a vicious way, also prevent fetal oxygen level to recover, even after placental oxygen adapted to normal limits. Hypoxia may further lead to meconium discharge and apoptosis. We found slightly higher levels of $\mathrm{CO}_{2}$ and bicarbonate and lower levels of $\mathrm{pH}$ and $\mathrm{O}_{2}$ in the umblical artery of fetuses with MSAF. Although only the $\mathrm{pH}$ value is statistically significant, these values further support our hypothesis of slight hypoxic state in the fetus with MSAF.

In conclusion, placental adaptation to fetal hypoxia may be responsible for the ultrastructural changes observed in the placentas with MSAF. The increased placental apoptosis in our study group may also be the result of the fetal hypoxia. Our ultrastructural and TUNEL findings suggest that MSAF in uncomplicated pregnancies may be due to a slight hypoxic state which does not cause any clinical complication or histological evidence of hypoxia.

\section{REFERENCES}

1. Cleary GM, Wiswell TE: Meconium-stained amniotic fluid and the meconium aspiration syndrome. An update. Pediatr Clin North Am 1998, 45:511-529

2. Hetts SW: To die or not to die: an overview of apoptosis and its role in disease. JAMA 1998, 279:300-307

3. Huppertz B, Hunt JS: Trophoblast apoptosis and placental development-a workshop report. Placenta 2000, 74-76

4. Smith SC, Baker PN, Symonds EM: Placental apoptosis in normal human pregnancy. Am J Obstet Gynecol 1997, 177: 57-65

5. Levy R, Nelson DM: To be, or not to be, that is the question. Apoptosis in human trophoblast. Placenta 2000, 21:1-13

6. Heazell A, Harris L, Forbes K, Crocer I: Placental cell turnover in health and disease. Reviews in Gynaecological and Perinatal Practice 2006, 6:80-86

7. Ishihara $\mathrm{N}$, Matsuo $\mathrm{H}$, Murakoshi $\mathrm{H}$, Laoag-Fernandez JB, Samoto T and Maruo T: Increased apoptosis in the syncytiotrophoblast in human term placentas complicated by either preeclampsia or intrauterine growth retardation. Am J Obstet Gynecol 2002, 186:158-166 
8. Smith SC, Baker PN, Symonds EM: Increased placental apoptosis in intrauterine growth restriction. Am J Obstet Gynecol 1997, 177:1395-1401

9. Axt R, Kordina AC, Meyberg R, Reitnauer K, Mink D, Schmidt W: Immunohistochemical evaluation of apoptosis in placentae from normal and IUGR pregnancies. Clin Exp Obstet Gynecol 1999, 26:195-198

10. Korkmaz A, Tekinalp G, Oran O, Yurdakök Y, Yiğit Ş, Çağlar M, Akçören Z, Önderoğlu L, Uçkan D: Placental apoptosis in pregnancies with intrauterine meconium passage. Am J Perinatol 2005, 22:133-138

11. Mvumbi L, Manci EA, Ulmer RD, Shah AK: Decreased placental and umbilical cord glycogen levels associated with meconium-stained amniotic fluid. Placenta 1998, 19:295-299

12. Redline RW, Faye-Petersen O, Heller D, Qureshi F, Savell V, Vogler C: Society for Pediatric Pathology, Perinatal Section, Amniotic Fluid Infection Nosology Committee. Amniotic infection syndrome: nosology and reproducibility of placental reaction patterns. Pediatr Dev Pathol 2003, 6:435-448

13. Kaplan C, Lowell DM, Salafia C: College of American Pathologists Conference XIX on the Examination of the Placenta: report of the working group on the definition ofstructural changes associated with abnormal function in the maternal/fetal/placental unit in the second and third trimesters. Arch Pathol Lab Med 1991, 115:709-716

14. Langston C, Kaplan C, Macpherson T, Manci E, Peevy K, Clark B, Murtagh C, Cox S, Glenn G: Practice guideline for examination of the placenta. Arch Pathol Lab Med 1997, 121:449-476
15. King EL, Redline RW, Smith SD, Kraus FT, Sadovsky Y, Nelson DM: Myocytes of chorionic vessels from placentas with meconium-associated vascular necrosis exhibit apoptotic markers. Human Pathol 2004, 35:412-417

16. Altshuler G, Hyde SR: Clinicopathologic implications of placental pathology. Clin Obstet Gynecol 1996, 39:549-570

17. Richey SD, Ramin SM, Bawdon RE, Roberts SW, Dax J, Roberts J, Gilstrap LC: Markers of acute and chronic asphyxia in infants with meconium-stained amniotic fluid. Am J Obstet Gynecol 1995, 172:1212-1215

18. Heifetz SA: The umbilical cord: obstetrically important lesions. Clin Obstet Gynecol 1996, 39:571-587

19. Benisrschke K: Obstetrically important lesions of the umbilical cord. J Reprod Med 1994, 39:262-272

20. Jazayeri A, Politz L, Tsibris JC, Queen T, Spellacy WN: Fetal erythropoietin levels in pregnancies complicated by meconium passage: Does meconium suggest fetal hypoxia? Am J Obstet Gynecol 2000, 183:188-190

21. Holubec H, Payne CM, Bernstein H, Dvorakova K, Bernstein C, Waltmire CN, Warneke JA, Garewal H: Assessment of apoptosis by immunohistochemical markers compared to cellular morphology in ex vivo-stressed colonic mucosa. J Histochem Cytochem 2005, 53:229-235

22. Macara L, Kingdom JCP, Kaufman P, Cohen G, Hair J, More IA, Lyall F, Greer IA: Structural analysis of placental terminal villi from growth-restricted pregnancies with abnormal umbilical artery doppler waveforms. Placenta 1996, 17:37-48

23. Soma H, Hata T, Oguro T, Fujita K, Kudo M, Vaidya U: Characteristics of histopathological and ultrastructural features of placental villi in pregnant Nepalese women. Med Mol Morphol 2005, 38:92-103 